\title{
Shallow aquifer potential mapping in the foothills of Churia in Eastern Gangetic Plain of Saptari District, Nepal
}

\author{
Bhesh Raj Thapa ${ }^{1}$ - Surendra Raj Shrestha ${ }^{2} \cdot$ Romulus Okoth Okwany $^{3} \cdot$ Madhu Neupane $^{2}$
}

Received: 13 August 2018 / Accepted: 5 May 2019 / Published online: 14 May 2019

(c) The Author(s) 2019

\begin{abstract}
The population living in the foothills of Churia, the study area, faces severe water scarcity due to limited access to surface water. The only alternative is groundwater, and there is extensive use of groundwater for domestic and agricultural purposes. Groundwater in some areas is limited and very limited information pertaining to the aquifer. In this context, this research tries to answer the pertinent questions concerning the aquifer properties, depth and thickness of the groundwater aquifer layer and groundwater prospects for irrigation. The objective of this research is to identify the aquifer properties and groundwater prospects using two-dimensional electrical resistivity tomography methods (2D-ERT). Five 2D-ERT profiles were used to collect information to a depth of around $40 \mathrm{~m}$, with minimum electrode spacing of $5 \mathrm{~m}$ over a profile length of $240 \mathrm{~m}$. The survey was carried out using Wenner electrode configurations. The resistivity tomogram sections were interpreted using RES2DINV software, which provides output in the form of resistivity contours that are used to draw up the lithological and geological information. The result of the survey indicates that the areas with good potential for groundwater access exist mostly along the southeast to central east parts of the study area, where there is gravel and sand with resistivity values between 100 and $500 \Omega \mathrm{m}$. Areas along the northwest with clay and silty clay formations have low resistivity values $(<70 \Omega \mathrm{m})$ and low groundwater potential. While the northeast has high resistivity values ( $>2000 \Omega \mathrm{m}$ ) due to sand formation underlain by boulder and cobbles, it also has limited groundwater potential due to the limited depth $(<6 \mathrm{~m})$ of sand and low storage capacity. The study reveals a variation in lithological formation, including a patchwork of clay, silty clay, sand, gravel and boulder materials, with varying groundwater potentials. When developing shallow tube wells in the study area, spatial variation in the productive aquifer, hydraulic conductivity of groundwater flow within and near the tapped aquifer and geological and lithological material need to be considered.
\end{abstract}

Keywords Aquifer potential $\cdot$ ERT $\cdot$ Groundwater prospects

\section{Introduction}

In recent years, the dependency on groundwater for both water supply and irrigation has increased and approximately one billion people rely on groundwater in India, China, Pakistan, Bangladesh and Nepal (FAO 2016), and the livelihoods of

Bhesh Raj Thapa

bthapa.ioe@gmail.com; B.thapa@cgiar.org

1 International Water Management Institute (IWMI), Nepal Office, Durbar Tole, Pulchowk-3, Lalitpur, G. P. O. Box 8975, EPC 416 Kathmandu, Nepal

2 Groundwater Resources Development Board, Babarmahal, Kathmandu, Nepal

3 Department of Agricultural Engineering, Egerton University, P. O. Box 536, Njoro, Kenya poor people in these areas are especially tied to groundwater access (Rijsberman 2003). Around 244.8 billion cubic meters $\left(\mathrm{Bm}^{3}\right)$ of groundwater are available in the Ganga River basin, with the highest potential in India $\left(168.7 \mathrm{Bm}^{3}\right)$, Bangladesh $\left(64.6 \mathrm{Bm}^{3}\right)$ and Nepal $\left(11.5 \mathrm{Bm}^{3}\right)$, of which an average of $54 \%$ has already been developed for irrigation, domestic, industrial and other purposes (Amarasinghe et al. 2016; Rajmohan and Prathapar 2013). Around $61 \%$ of available resources in India, $10 \%$ in Nepal and $45 \%$ in Bangladesh are already in use. Available resources that have not been fully accessed in Nepal need to be identified to ensure the supply of drinking and irrigation water in the Terai region of Nepal.

Saptari District, the focus of this study, lies in the eastern Terai region along the southern foothills of the Siwalik (Churia) range in Nepal and depends upon groundwater for both drinking and irrigation purposes. Even though several 
southern rivers drain through Siwalik to Terai, people residing in these areas are facing water scarcity for both drinking and irrigation (Pathak 2016). In recent decades, the population of the previously sparse Churia range has been increasing and most of the agricultural lands have been developed. These fields have come to depend on rain-fed cultivation as surface irrigation is limited, and groundwater access has not been sufficient. In this context, action research on Dry Season Irrigation for Marginal and Tenant Farmers (DSI4MTF) in the study area (Kanakpati Village Development Committee (VDC), North of East-West Highway) is being implemented. Interventions include the construction of shallow tube wells, introduction of microirrigation techniques for the efficient use of water, conjunctive use of surface and groundwater, focusing on marginalized and tenant farmers through collective approaches, efficient use of available energy sources and linking high value products with market.

The study area, Kanakpatti VDC (located in the Siwalik foothill), is bounded between the Siwalik range to the north and Indo-Gangetic Plain (IGP) to the south. The Siwalik range has sedimentary rock, mainly the alternating bed of sandstone and mudstone and conglomerate (Pathak 2016). The coarse sand, gravel, pebble, cobble and boulders are in existence in the southern part (Bhabar zone) and become finer southwards in IGP (Pathak 2016). In Bhabar zone, porous geology exists, which enhances the recharge, but water availability is still restricted at the shallow aquifer due to the deeper water table. Construction of shallow tube wells, as part of the DSI4MTF project, revealed varying yield characteristics of the shallow aquifer. Many of the wells constructed yielded little or no water, further demonstrating that aquifer response and information in Siwalik foothill would be very useful. A desire to better understand and locate potential groundwater zones, given the water scarcity in the area, motivated this study's exploration of the aquifer using electrical resistivity investigation (ERI).

ERI is low expensive, field operation is easy, portable, greater depth of penetration and hence wide range of applicability, which shows the bulk resistivity values (Bhattacharya and Patra 1968; Ishara-remo 2016; Keller 1986; Kelly 1977; Olorunfemi et al. 2009; Robert et al. 2011). Each range of bulk resistivity values has its own significance or characteristics of aquifer properties (Kumar et al. 2014; Mohamaden 2016) for groundwater prospecting. Those techniques are useful to determine the subsurface structure of basin, determination of horizontal and vertical distribution of aquifer and tracing groundwater movement. In addition to this, detailed investigation of artificial recharge, determination of groundwater potential zone and depth to groundwater table (Amarasinghe et al. 2016; Giao et al. 2003; Keller 1986; Kelly 1977; Rajmohan and Prathapar 2013; Robert et al. 2011; Samouëlian et al. 2006) also can be investigated using ERI. Hence, ERI has been used in this study to determine the aquifer layer properties and groundwater potential zones, which will provide essential information for the small land holding farmers in the study area to develop the shallow tube well.

In this context, this research tries to answer the pertinent questions to understand the aquifer properties (clay, sand, bedrock-limit depth of drilling), the depth and thickness of the groundwater aquifer layer, and its groundwater storage and yield prospects. The objective of this research is to identify aquifer material properties like depth and thickness of aquifer layer and to identify and zonation of groundwater potential zone within the intervention site.

\section{Materials and methods}

For this investigation, 2D-ERT techniques were selected to determine the thickness and resistivity of layered media for assessing groundwater potential zone and identification of area for tube well development under the DSI4MTF project in the Eastern Gangetic Plains (EGP) at Kanakpatti VDC of Saptari District.

Electrical resistivity investigation (ERI) method is a versatile and economical technique for groundwater prospecting in different geological settings due to its wide spectrum of resistivity range compared to other geophysical parameters (Kumar et al. 2014; Mohamaden 2016). It also has numerous advantages over the conventional vertical electric sounding (VES) method, which assumes 1D earth model (which does not occur in most of the practical cases), acquires a limited number of data points, takes longer for data acquisition and provides poor resolution information (Bhattacharya and Patra 1968). For these reasons, the direct current electrical resistivity investigation technique is being widely used to image the hydrogeological structure of shallow subsurface earth (Giao et al. 2003; Keller 1986; Kumar et al. 2007). The two-dimensional electrical resistivity tomography (2D-ERT) technique, in particular, is widely used and applied by many researchers (Griffiths and Barker 1993; Robert et al. 2011). The interpreted 2D inverted resistivity model of the subsurface represents the hydrogeological condition, structural features and resistive and conductive formation (Griffiths and Barker 1993; Kelly 1977; Ratnakumari et al. 2012).

\section{Study area}

The study area covers an area of approximately $0.5 \mathrm{~km}^{2}$ and is one of the implementation sites of the DSI4MTF project (Fig. 1). The 2D-ERT investigation was planned to transect through two of the areas where hydrogeological concerns were identified in the siting of groundwater tube wells. The study area, Kanakpatti VDC is located in the Siwalik foothill and is bounded between the Siwalik range to the north 
Fig. 1 Study area showing the electrical resistivity tomography line in Kanakpatti, Saptari District

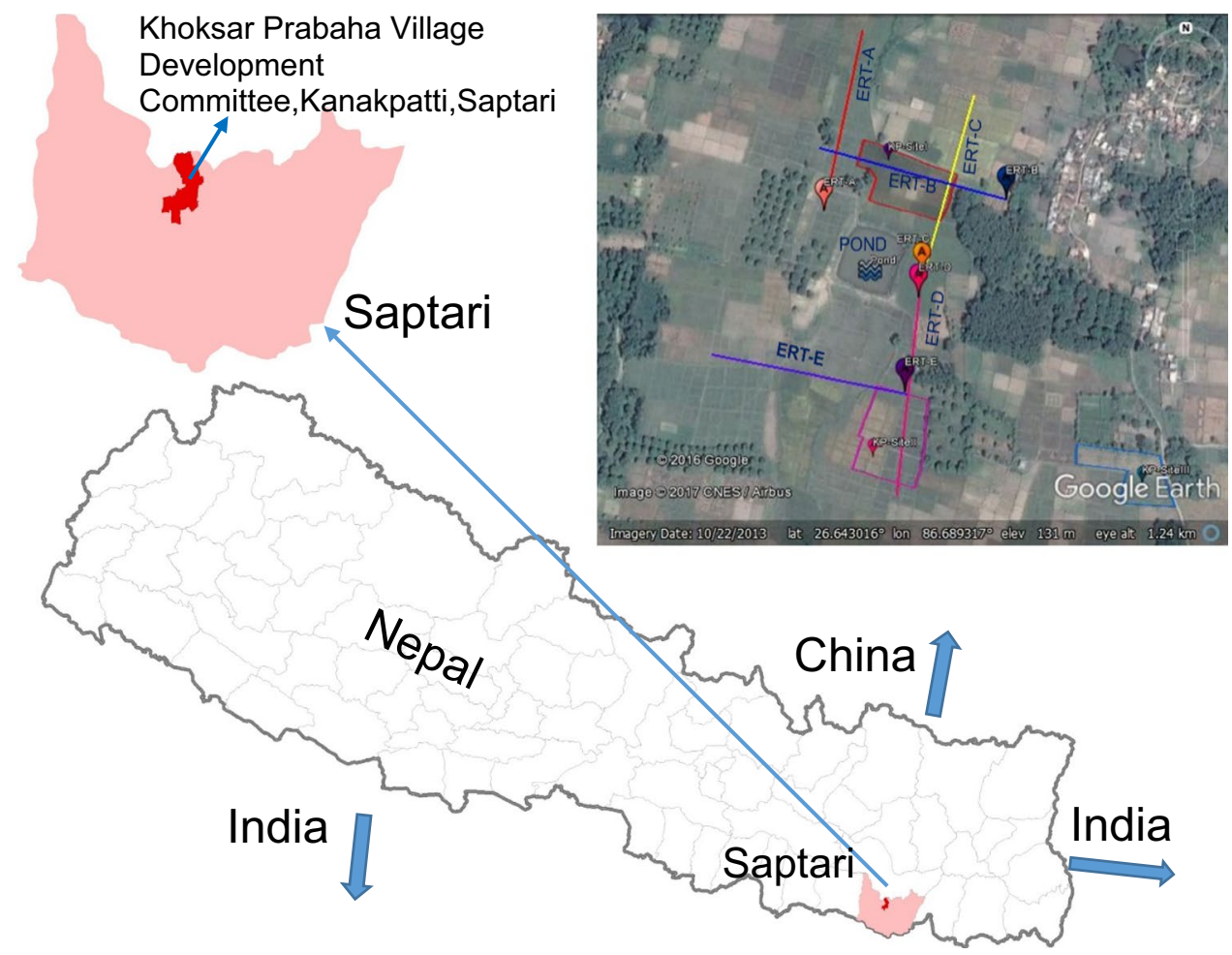

Khoksar Prabaha Village

Committee,Kanakpatti,Saptari

Saptari

and Eastern Gangetic Plain (EGP) to the south. Most of the households have shallow tube wells used for drinking water. In the intervention sites, two ponds and significant number of tube wells are used for irrigation. The wide variation in lithological section across the study site motivated the investigation of the groundwater potential zones, prospects and aquifer layer.

\section{Electrical resistivity tomography (ERT) investigation}

Two-dimensional electrical resistivity tomography (2DERT) techniques using Wenner arrays were used to investigate the properties of material at a depth of $40 \mathrm{~m}$. The choice of an array and the distance between the electrodes is very important for obtaining accurate information on subsurface geology. The methodological approaches used in this study are described in below.

\section{Design of survey}

ERT survey was designed considering the arrangement of four electrodes, two current electrodes (C1 and C2) and two potential electrodes (P1 and P2). The schematic configuration of Wenner array employed is as shown in Fig. 2a, b. This study used Wenner array, based on its advantages of high signal-to-noise ratio, symmetrical array and symmetrical anomalies, good lateral resolution (Coggon 1973; Dey et al. 1975) and good vertical resolution (Loke 1999).

\section{Data acquisition}

The electrical resistivity survey equipment consists of a transmitter, receiver, power supply, stainless steel electrodes and shielded cables. Five 2D-ERT profiles were carried out with a full length of profile of $240 \mathrm{~m}$, which will provide subsurface lithological information about a depth of $40 \mathrm{~m}$ and minimum electrode spacing of $5 \mathrm{~m}$. The location and profile coverage for 2D-ERT are presented in Fig. 1 and Table 1. The survey was carried out using Wenner array of electrode configurations. In the present study a GEmotive, GD10 instrument was used, which computes and displays apparent resistivity data to obtain a continuous coverage of the subsurface properties along the line of investigation.

\section{Data processing, analysis and interpretation}

The results of the geo-electrical survey were processed and quantitatively interpreted using available geological information and presented as geo-electrical sections along the various profiles. The resistivity field data was first processed by eliminating any outlier data points, and then, damping and mesh parameters were assigned to the individual data set to achieve the realistic subsurface resistivity model. The interpretation of electrical resistivity data is the process of deriving the values of true resistivity's $(\rho)$ and thicknesses $(t)$ of various subsurface strata from the values of recorded resistance $(R)$ or apparent resistivity

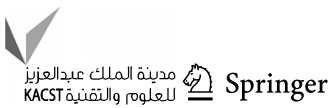




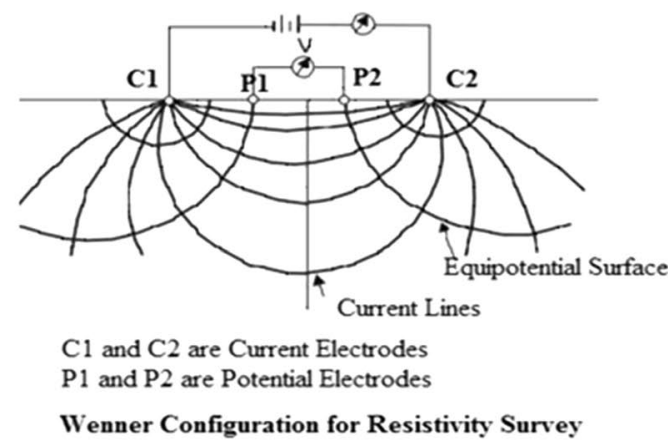

(a)

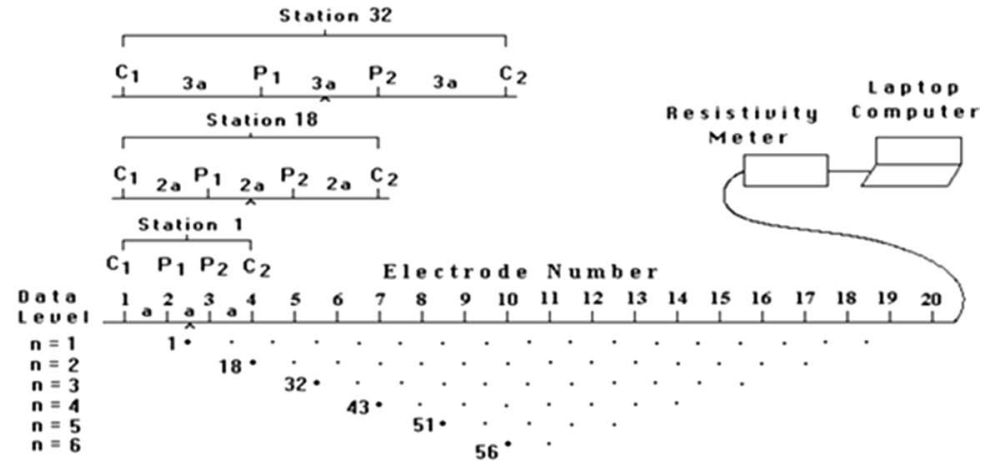

(b)

Fig. 2 Schematic of a Wenner configuration for resistivity survey (Marescot et al. 2008) and b sequence of measurement to build up a pseudosection (Loke 1999)

Table 1 Two-dimensional ERT coverage (all profiles at $240 \mathrm{~m}$ )

\begin{tabular}{llll}
\hline Profile no. & \multicolumn{2}{l}{ ERT GPS coordinates $\left(^{\circ}\right)$} & Profile orientation \\
\cline { 2 - 3 } & Start & End & \\
\hline ERT-A & $26.644 / 86.691$ & $26.646 / 86.691$ & South to North \\
ERT-B & $26.644 / 86.693$ & $26.645 / 86.691$ & East to West \\
ERT-C & $26.643 / 86.622$ & $26.645 / 86.693$ & South to North \\
ERT-D & $26.643 / 86.692$ & $26.641 / 86.692$ & North to South \\
ERT-E & $26.642 / 86.692$ & $26.642 / 86.689$ & East to West \\
\hline
\end{tabular}

$(\rho a)$ at electrode separations $(a)$. There are a number of interpretation techniques for evaluating $(\rho)$ and $(t)$ of each of the stratum as proposed by many investigators.

The processed field data are presented in the form of resistivity pseudo-sections using the schematic shown in Fig. 2b) with dense sampling of apparent resistivity measurement (Loke 1999). The processed and filtered data were inverted using least-squares inverse approach with a standard Gauss-Newton optimization technique by the help of computer software RES2DINV (Loke 1999; Muchingami et al. 2012). The software inverts the field data, calculates the appropriate model in term of resistivity and provides output in the form of resistivity contours. The final inverted resistivity models provide an approximate image of the subsurface geology and hydrogeology, reproducing an approximate subsurface resistivity variation with depth in both vertical and lateral directions.

The resistivity of any given layer depends upon rock type, grain size, degree of void spaces and amount of water present, degree of weathering, mineral constituents and inter-granular compaction (Marescot et al. 2008). However, the inverted $2 \mathrm{D}$ resistivity section, which approximates the subsurface resistivity, is finally interpreted in terms of hydrogeology and geology in the present local hydrogeological context.
In the context of soil mapping, electrical resistivity exhibits large range of values varying from $1 \mathrm{O}$ in saline soil to as high as $10^{5} \mathrm{O}$ in dry soil overlaying crystalline rock (Samouëlian et al. 2006). In the present study, correlation of resistivity ranges with expected lithology and groundwater potentials were interpreted by adopting the guidelines of Table 2 developed by the Groundwater Resources Development Board (GWRDB) based on previous field studies carried out in different parts of Nepal and informed by local geological information, correlation of resistivity value of the exposed bedrocks and overburden deposit on the surface. For the similar materials, the resistivity value will be different for saturated and dry condition. The unsaturated layer is generally characterized by high resistivity values, whereas the water-saturated layer shows zone of low resistivity. At the same time, resistivity values vary with material types, and hence, the lithology data collected by GWRDB in the vicinity area were correlated with the resistivity ranges for interpreting the groundwater prospects.

Table 2 Typical ranges of electrical resistivity of earth materials, corresponding geological formation, groundwater and unpublished reports from GWRDB of Nepal

\begin{tabular}{lll}
\hline Resistivity range $(\Omega \mathrm{m})$ & Expected lithology & $\begin{array}{l}\text { Groundwater } \\
\text { Prospects }\end{array}$ \\
\hline$>1000-5000$ & $\begin{array}{l}\text { Boulder, cobble, pebble } \\
\text { unsaturated fractured } \\
\text { bedrock } \\
\text { Gravel, coarse sand }\end{array}$ & Poor \\
$250-1000$ & Fine to coarse sand & Good \\
$100-200$ & Silt, fine sand & Pood \\
$50-100$ & Silt, clay & Poor \\
$20-50$ & Clay & Poor \\
$<20$ & &
\end{tabular}




\section{Results}

The variation in modeled electrical resistivity in depth along the line of investigation was presented through resistivity tomogram sections. Those variations in modeled physical properties have relation with the subsurface geological and hydrogeological setup, which are presented for each profile (five profile) and their hydrogeological and lithological interpretation through representative tomogram section in subsequent figures. Geological/lithological information extracted from the ERT results representing resistivity contour values are presented in the figures. The 2D-ERT displays a variation in resistivity values both vertically and horizontally, indicating that subsurface geological formations strongly vary in their electrical properties. All the profiles were near the pond shown in Fig. 1a and described with reference to the pond.

\section{Profile along ERT-A}

This profile runs from south to north. The location lies about $20 \mathrm{~m}$ north of the pond in the project area as shown in Fig. 1a). The inverted resistivity section shows resistivity depth modeled to $42 \mathrm{~m}$, as shown in Fig. 3. This lithological section can be interpreted as a multi-layered model. Low resistivity values of less than $70 \Omega \mathrm{m}$ dominate in the area, which indicates the presence of unsaturated formations consisting of silty clay. Within this dominant silty clay layer, there is a patch of clay at the lateral distance $50-60 \mathrm{~m}$ about $6-\mathrm{m}$ thick at a depth of $6 \mathrm{~m}$. The ERT values indicate that the area has no productive aquifer within the tested depth.

\section{Profile along ERT-B}

This ERT profile runs from east to west, with east being the starting point located about $75 \mathrm{~m}$ north of the pond. A marked variation in lithology is observed. A high resistivity value greater than $150 \Omega \mathrm{m}$ is found in the lateral distance of $10-60 \mathrm{~m}$ at a depth of $>6 \mathrm{~m}$ and is around $12-\mathrm{m}$ thick, where sand dominates. From the center to west of the transect (120-240 m lateral distance), there are resistivity values $<70 \Omega$, consisting of a silty clay lithological formation. In this area, there are only a few patches where shallow tube wells could be constructed up to a depth of $18 \mathrm{~m}$. If we look from the groundwater prospects, shallow tube wells can be developed in the eastern part of the profile up to 80 -m lateral direction. The rest of the area consists of mainly clay and silty clay, which is not feasible for the development of shallow tube well (Fig. 4).

\section{Profile along ERT-C}

The third ERT transect ran from south to north. The starting point was located about $30 \mathrm{~m}$ west of the pond. There is a marked variation in lithology and structure in this area. The resistivity section shows resistivity values $>2000 \Omega \mathrm{m}$ toward the central to northern part of the profile in the depth of $>6 \mathrm{~m}$, which suggests the existence of boulder and cobble. This signifies the existence of Bhabar zone materials, which may act as a recharge pool for the deep groundwater system. The existence of sand gravel with resistivity values between 100 and $500 \Omega \mathrm{m}$ indicates aquifer with potential high yield up to a depth of $6 \mathrm{~m}$. Interestingly, this suggests that the water available in this zone discharges into the deep groundwater system and is not feasible for shallow tube well development given that water level will be too deep for surface pumps. Similarly, while moving from south to north in lateral direction up to $120 \mathrm{~m}$, resistivity values between 100 and $500 \Omega \mathrm{m}$ are observed up to a depth of about $25 \mathrm{~m}$. This suggests the subsurface lithology section consists of sand and gravel which are very good aquifers. With respect to groundwater potential prospects, the southern to central part of the area has potential for shallow tube well development while the northern part has potential up to a depth of $6 \mathrm{~m}$. However, the development of such wells is likely to be poor due to the presence of large boulders and cobble (Fig. 5).

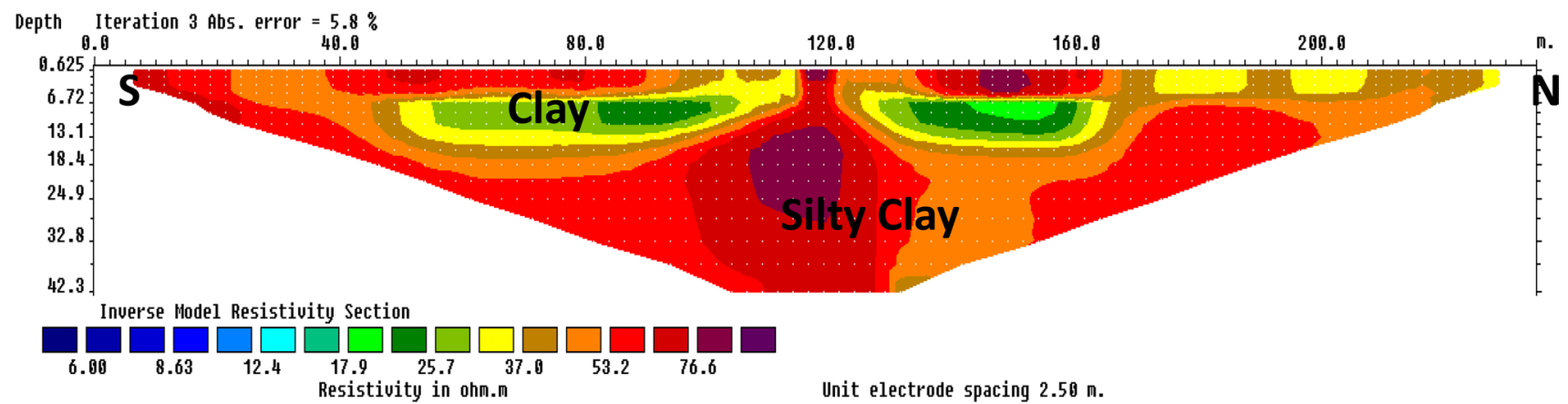

Fig. 3 Resistivity tomogram along profile ERT-A 


\section{Profile along ERT-D}

This profile also runs from north to south. This profile is a continuation of the profile ERT-C. In this resistivity section, most of the resistivity values are 50-150 $\Omega \mathrm{m}$, suggesting the domination of a sandy layer up to a depth of $20 \mathrm{~m}$. Figure 6 shows that the subsurface lithology consists of two layers, an upper sandy layer up to depth of about $20 \mathrm{~m}$ underlain by a silty clay layer to a depth of about
$42 \mathrm{~m}$. This part of the area exhibits good potential for shallow tube well development.

\section{Profile along ERT-E}

This profile runs east to west due south of the pond. The central resistivity section, from about $80-160 \mathrm{~m}$ of the profile, has resistivity values of $<70 \Omega \mathrm{m}$, which suggests the subsurface geological section has a poor aquifer due to
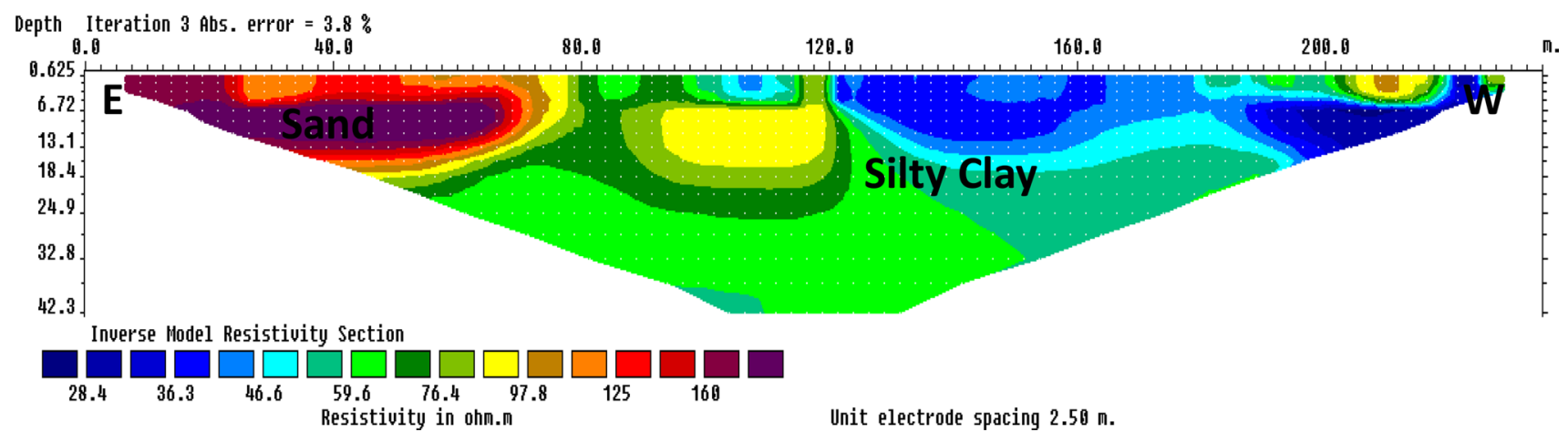

Unit electrode spacing $2.50 \mathrm{~m}$.

Fig. 4 Resistivity tomogram along profile ERT-B

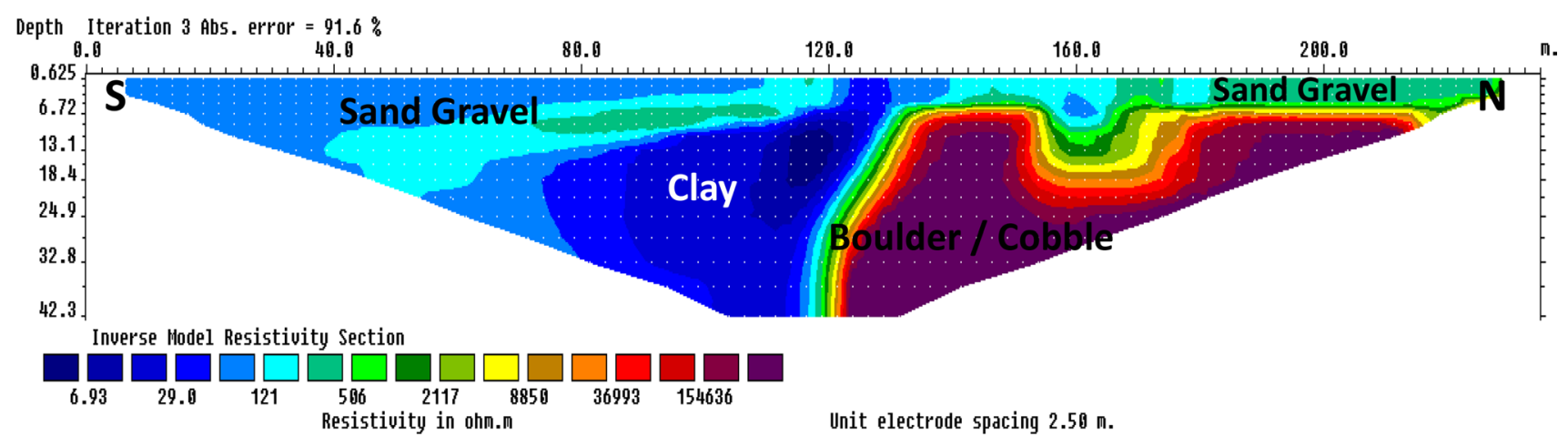

Fig. 5 Resistivity tomogram along profile ERT-C

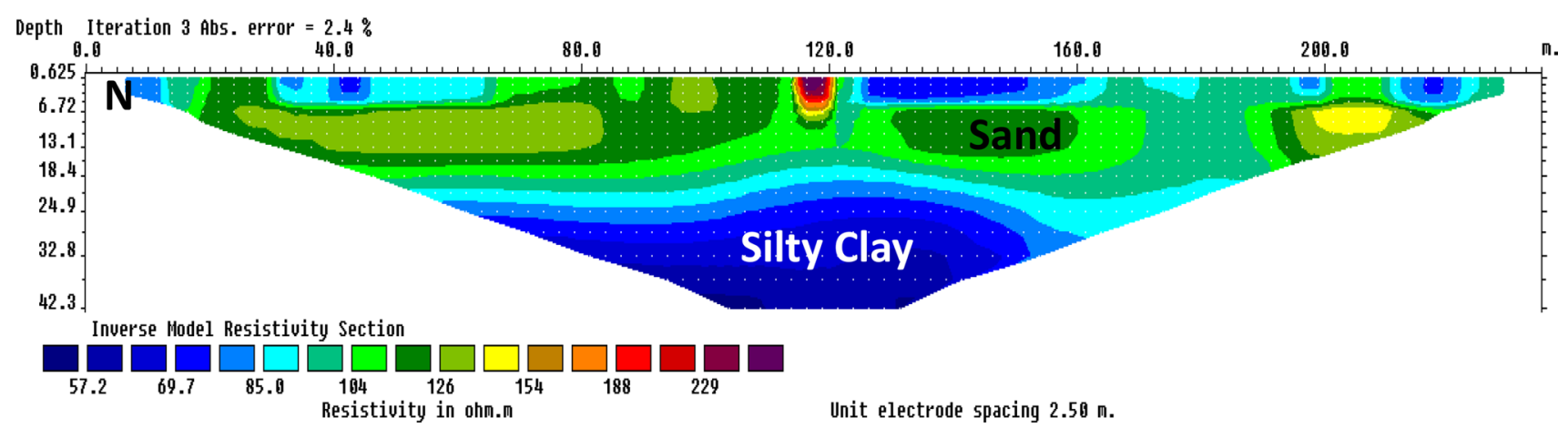

Fig. 6 Resistivity tomogram along profile ERT-D 
dominant silty clay aquifer materials. In both the eastern and western section, the resistivity values are 100-350 $\Omega \mathrm{m}$, at a depth up to approximately $13 \mathrm{~m}$, which shows a gravel and sand subsurface. The eastern parts have the greatest potential for shallow tube well development, and well depth in the eastern and western parts should not exceed 13 m (Fig. 7).

\section{Discussion and conclusion}

The objective of this research was to identify and zonation of groundwater potential area within the study area by investigating the shallow subsurface aquifer material properties and distribution of depth using 2D-ERT techniques. During the shallow tube well design and development in the study area, some areas did not have good potential, which motivated this investigation to understand the aquifer properties, material, depth and potential zones. The 2D-ERT survey was oriented around the central pond having five ERT profiles, each with a length of $240 \mathrm{~m}$, were prepared. From the transect profiles of resistivity, an assessment of the aquifer material was made to provide insight of groundwater potential zone around pond.

Table 3 and Fig. 9 describe the general spatial mapping of the dominant geological characteristics and groundwater potential of the study area. The results show that most of the study areas are underlain by silty clay from a depth of
10-18 m, except for the northeast corner of the study area, which is underlain by boulders and cobble (Fig. 8). The section of ERT profile A and lateral distance of 80-240 m along the section of ERT-B are dominated by silty clay and clay particles, which can be zoned as poor aquifer zone A (Fig. 9) which is not favorable for shallow tube well development. Similarly, lateral distance $0-80 \mathrm{~m}$ of ERT profile $\mathrm{B}$ and $0-120 \mathrm{~m}$ of ERT profile $\mathrm{C}$ up to 5-10 $\mathrm{m}$ depth show sand and gravel. As a continuation of ERT profile $\mathrm{C}$, there is also aquifer material of sand and gravel in shallow depth up to $6 \mathrm{~m}$, and beneath this depth boulder and cobble dominates the aquifer material. This section can be zoned as limited groundwater potential aquifer (zone B in Fig. 9) with low storage capacity of aquifer material. ERT profile $\mathrm{C}$ lateral distance up to $40 \mathrm{~m}$ shows an upper layer consisting of clay and good aquifer material of sand and gravel on limited depth up to $13 \mathrm{~m}$ in the eastern part, underlain by silty clay along the ERT profile E. This can be zoned as good groundwater potential aquifer (zone $\mathrm{C}$ in Fig. 9) within the sandy aquifer. The lateral distance (8-240 $\mathrm{m}$ ) along the ERT profile $\mathrm{E}$, where dominant sand aquifer material exists in a depth up to 5-10 $\mathrm{m}$, can be zoned as limited groundwater potential (zone D in Fig. 9). Table 3 summarizes the aquifer structure of the different zones as identified and mapped from five electrical resistivity sections.

The findings from this study align with the observations, perceptions and experiences of the farmers when developing
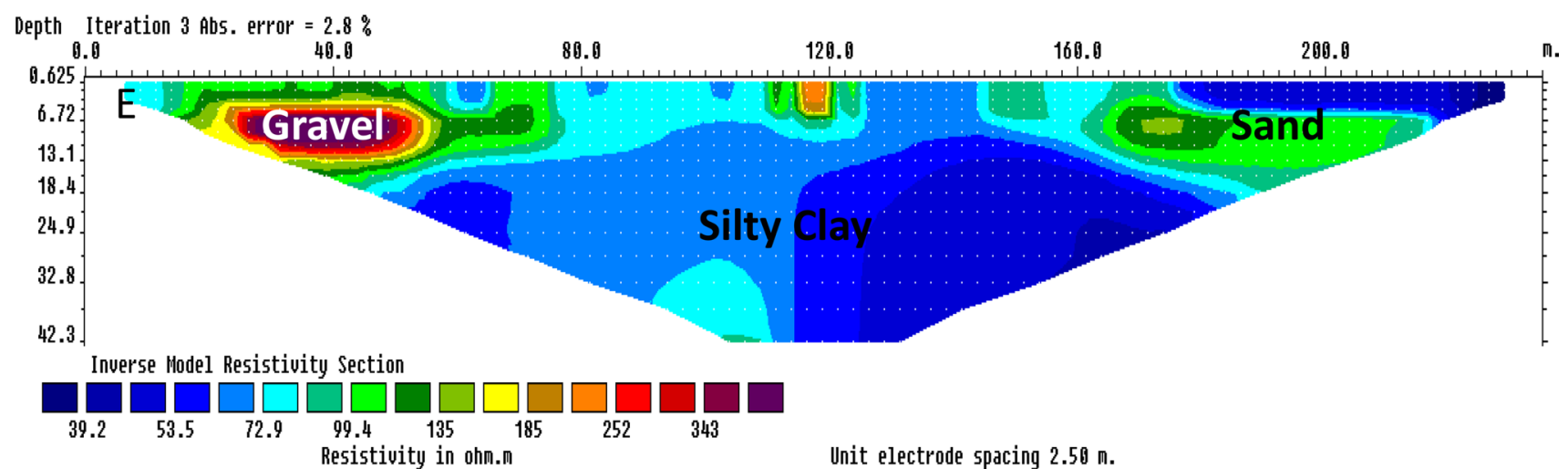

Unit electrode spacing $2.58 \mathrm{n}$.

Fig. 7 Resistivity tomogram along profile ERT-E

Table 3 Spatial distribution of aquifer characteristics and their groundwater prospects

\begin{tabular}{llc}
\hline Zone & Characteristics & Groundwater prospects \\
\hline A & Clay lenses underlain by silty clay. Area has very poor aquifer for the depth of assessment & Poor aquifer \\
B & Limited depth of sand aquifer (between 5 and $10 \mathrm{~m}$ ) underlain by gravel, boulder and cobble & $\begin{array}{c}\text { Less to moderate aquifer } \\
\text { having low storage } \\
\text { capacity }\end{array}$ \\
C & Sand and few lenses of gravel material to depths of 13-15 m, underlain by silty clay & Good potential aquifer \\
D & Shallow sand aquifer $(5-10 \mathrm{~m}$ ) underlain by silty clays & Less to moderate aquifer \\
\hline & &
\end{tabular}




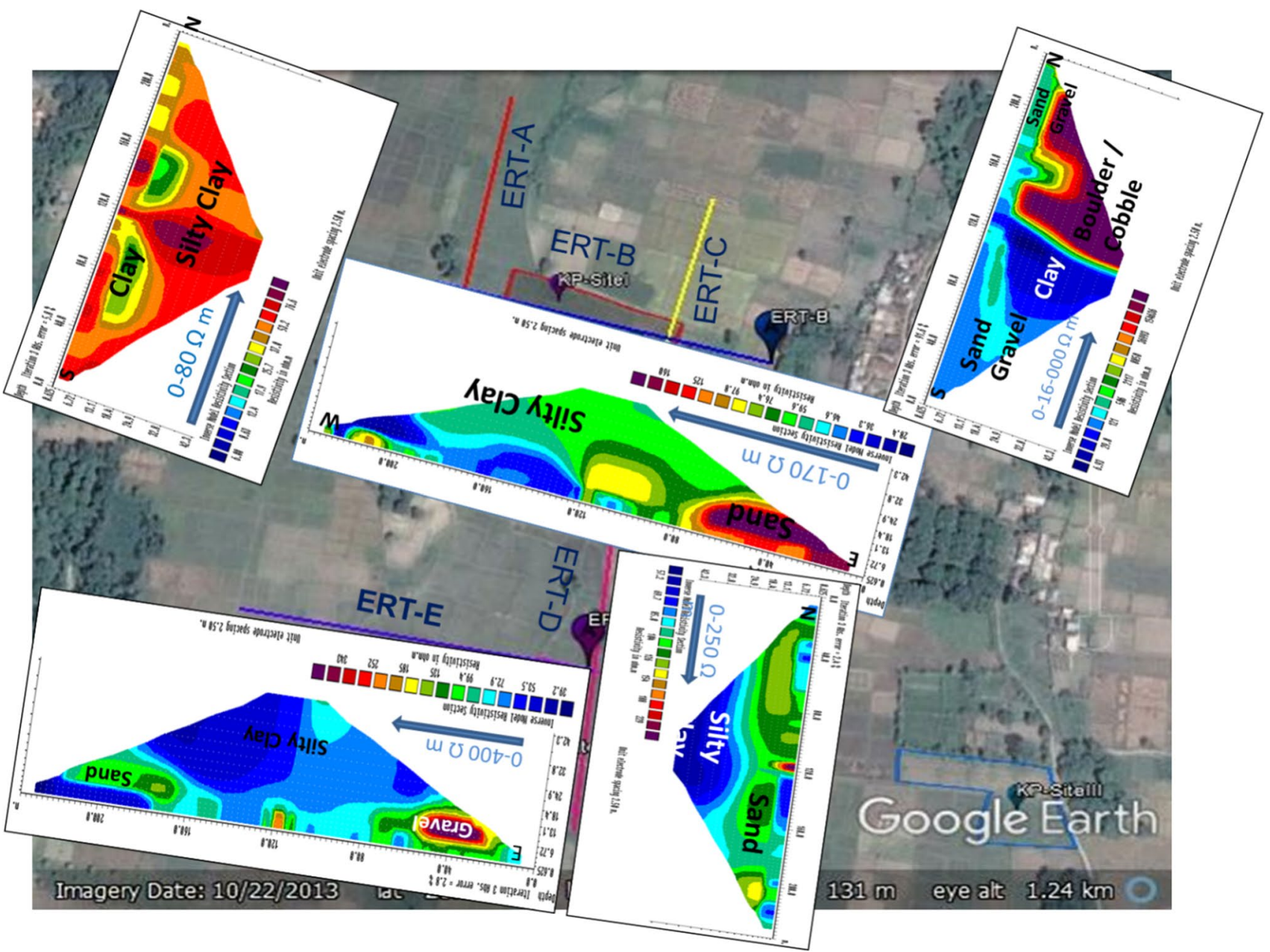

Fig. 8 Resistivity section along five ERT profiles

the groundwater infrastructure. The historical lack of farming activities in the area around the southwest corner of the study area also indicates the community's experience of limited water availability in this area. The study confirms the limited water availability and unsuitability of shallow tube wells within zone A and zone B. The study also highlights the successful water retention capability of the pond between site I and site II as it points to the likelihood that the pond is located at the area underlain by silty clay with low deep percolation.

However, ERI only provides rough estimate of groundwater potential and aquifer properties, and this study is helpful for farmers to identify the groundwater prospects zones. This study provided the depth of aquifer layer with types of aquifer material, and zonation of groundwater prospects even though having the limitation of ERI survey. Due to those limitations, DSI4MTF is also performing the pumping test in this area, which will prepare the spatial distribution map of aquifer properties, groundwater depth and flow direction, which is not scoped out in this study. The results of the survey indicate good groundwater potential along the southeast to central east parts of the study area (primarily zone C). The results illustrate a patchwork of clay, silty clay, sand, gravel and boulder materials, which provide for varied aquifer potentials. This explains varied success to date in locating tube wells in productive lenses of aquifer material. When developing shallow tube wells, spatial variation in the productive aquifer, hydraulic conductivity of groundwater flow within and nearby the tapped aquifer, and geological and lithological material need to be considered. The followup studies of this project having detail pumping test will help to optimize, design and sitting of the shallow tube wells. This technique is expensive, and farmers could not conduct at field level by themselves. Hence, government authorities like GWRDB can conduct such kind of survey based on geological properties across the country. In addition to this, high-resolution map can be produced by them, 


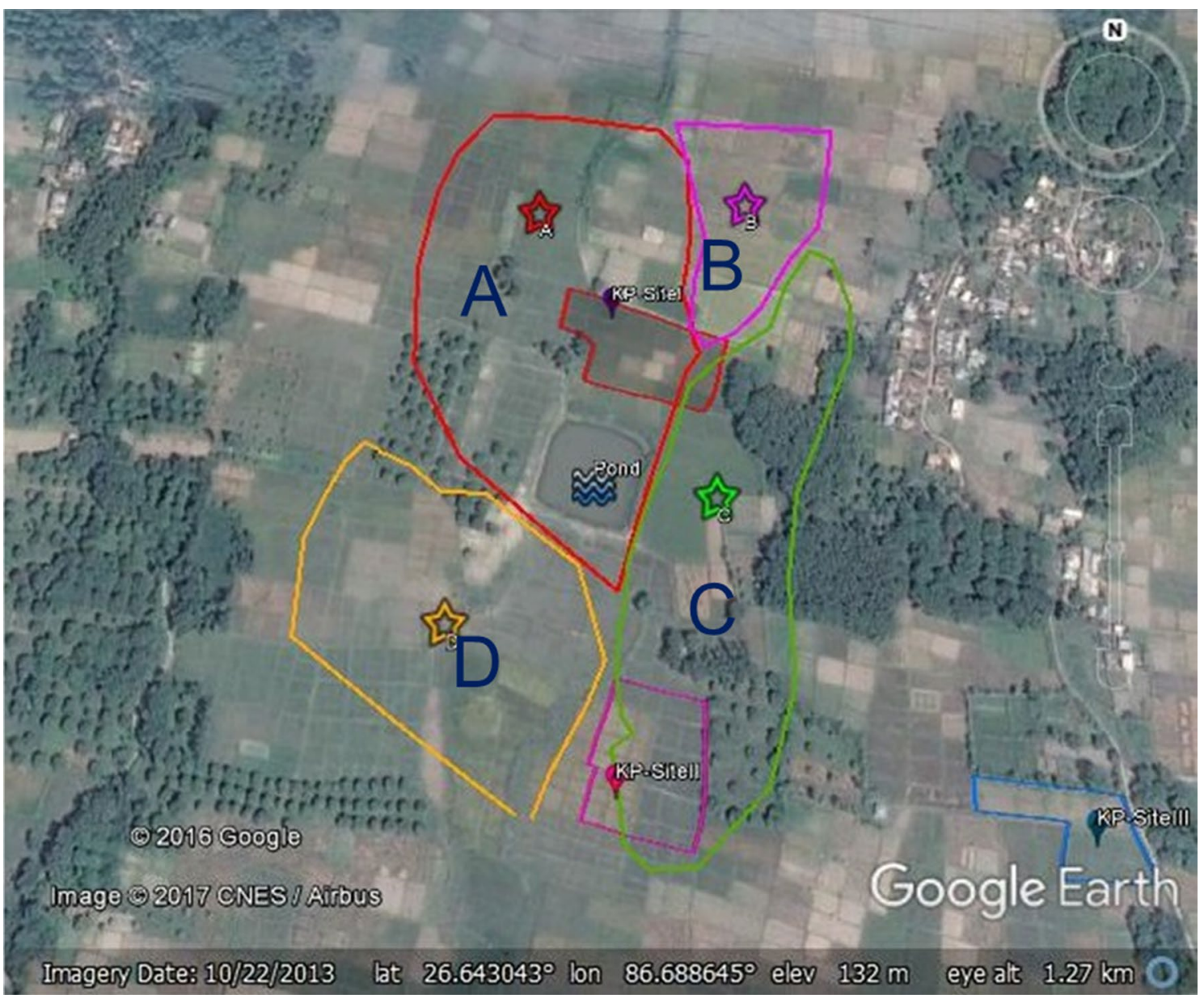

Fig. 9 Zonation of aquifer properties based on the aquifer structure and potential

and farmers and developers can access those map while developing groundwater project in particular area.

Acknowledgements We are very much thankful to Ram C. Bastakoti, Manita Raut, Rabindra Karki, Erik Schmidt and Michael Scobie for their continuous support for carrying out the field activities. We highly appreciate the Groundwater Resources Development Board (GWRDB), Nepal, for providing equipment and the Department of Irrigation and International Development Enterprises (IDE), Nepal, for providing support during the study. We are also thankful to University of Southern Queensland for providing technical support. We also appreciate Patrick Drown, Vishnu Prasad Pandey and Claire Swingle for reviewing the write-up for effective communication and Raj Kishor Roy for assisting in field work. Lastly, we express our sincere gratitude to the Australian Center for International Agriculture research (ACIAR) and the CGIAR programme for Water Land and Ecosystems (WLE) for providing the funding to carry out the project on improving dry season irrigation for marginal and tenant farmers in the Eastern Gangetic Plains through which this study was implemented.

Open Access This article is distributed under the terms of the Creative Commons Attribution 4.0 International License (http://creativeco mmons.org/licenses/by/4.0/), which permits unrestricted use, distribution, and reproduction in any medium, provided you give appropriate credit to the original author(s) and the source, provide a link to the Creative Commons license, and indicate if changes were made.

\section{References}

Amarasinghe UA, Muthuwatta L, Surinaidu L, Anand S, Jain SK (2016) Reviving the Ganges water machine: potential. Hydrol Earth Syst Sci 20(3):1085-1101. https://doi.org/10.5194/hess-20-1085-2016

Bhattacharya PK, Patra HP (1968) Direct current geoelectric sounding: principles and interpretation. Methods Geochem Geophys 9:135

Coggon JH (1973) A comparison of IP electrode arrays. Geophysics 38(4):737-761. https://doi.org/10.1190/1.1440372

Dey A, Meyer WH, Morrison F, Dolan WM (1975) Electric field response of two-dimensional inhomogeneities to unipolar and bipolar electrode configurations. Geophysics 40(4):630-640

FAO (Food and Agriculture Organization of the United Nation) (2016) AQUASTAT main database. FAO's information system on water and agriculture. http://www.fao.org/nr/water/aquastat/data/query /results.html. Accessed 9 Aug 2018

Giao PH, Chung SG, Kim DY, Tanaka H (2003) Electric imaging and laboratory resistivity testing for geotechnical investigation of Pusan clay deposits. J Appl Geophys 52(4):157-175. https://doi. org/10.1016/S0926-9851(03)00002-8 
Griffiths D, Barker R (1993) Two-dimensional resistivity imaging and modelling in areas of complex geology. J Appl Geophys 29(34):211-226. https://doi.org/10.1016/0926-9851(93)90005-J

Ishara-remo S (2016) Electromagnetic VLF survey for groundwater development in a contact terrain; a case study of Ishara-remo, Southwestern Nigeria. Electromagnetic Vlf survey for groundwater development in a contact terrain; a case (September 2009)

Keller GV (1986) An introduction to geophysical exploration. EOS Trans Am Geophys Union 67(11):132. https://doi.org/10.1029/ EO067i011p00132-01

Kelly WE (1977) Geoelectric sounding for estimating aquifer hydraulic conductivity. Groundwater 15:420-425. https://doi. org/10.1111/j.1745-6584.1977.tb03189.x

Kumar D, Ahmed S, Krishnamurthy NS, Dewandel B (2007) Reducing ambiguities in vertical electrical sounding interpretations: a geostatistical application. J Appl Geophys 62(1):16-32. https:// doi.org/10.1016/j.jappgeo.2006.07.001

Kumar D, Rao VA, Sarma VS (2014) Hydrogeological and geophysical study for deeper groundwater resource in quartzitic hard rock ridge region from 2D resistivity data. J Earth Syst Sci 123(3):531543. https://doi.org/10.1007/s12040-014-0408-1

Loke DM (1999) Electrical imaging surveys for environmental and engineering studies. Cangkat Minden Lorong 6574525(1999):63. https://doi.org/10.3390/su8111117

Marescot L, Monnet R, Chapellier D (2008) Resistivity and induced polarization surveys for slope instability studies in the Swiss Alps. Eng Geol 98(1-2):18-28. https://doi.org/10.1016/j.engge o.2008.01.010

Mohamaden MII (2016) Delineating groundwater aquifer and subsurface structures by using geoelectrical data: case study (Dakhla Oasis, Egypt). NRIAG J Astron Geophys 5(1):247-253. https:// doi.org/10.1016/j.nrjag.2016.05.001
Muchingami I, Hlatywayo DJ, Nel JM, Chuma C (2012) Electrical resistivity survey for groundwater investigations and shallow subsurface evaluation of the basaltic-greenstone formation of the urban Bulawayo aquifer. Phys Chem Earth 50-52:44-51. https:// doi.org/10.1016/j.pce.2012.08.014

Olorunfemi MO, Ojo JS, Akintunde OM (2009) Hydro-geophysical evaluation of the groundwater potentials of the Akure metropolis, southwestern Nigeria. J Min Geol 35:207-228

Pathak D (2016) Water availability and hydrogeological condition in the Siwalik foothill of east Nepal. Nepal J Sci Technol 17(I) (Dmg 1984):31-38

Rajmohan N, Prathapar SA (2013) Hydrogeology of the eastern Ganges Basin: an overview. https://doi.org/10.5337/2013.216

Ratnakumari Y, Rai SN, Thiagarajan S, Kumar D (2012) 2D Electrical resistivity imaging for delineation of deeper aquifers in a part of the Chandrabhaga river basin, Nagpur District, Maharashtra, India. Curr Sci 102(1):61-69

Rijsberman F (2003) Can development of water resources reduce poverty? Water Policy 5(September):399-412

Robert T, Dassargues A, Brouyère S, Kaufmann O, Hallet V, Nguyen F (2011) Assessing the contribution of electrical resistivity tomography (ERT) and self-potential (SP) methods for a water well drilling program in fractured/karstified limestones. J Appl Geophys 75(1):42-53. https://doi.org/10.1016/J.JAPPGEO.2011.06.008

Samouëlian A, Cousin I, Tabbagh A, Bruand A, Richard R (2006) Electrical resistivity survey in soil science: a review. hal-00023493

Publisher's Note Springer Nature remains neutral with regard to jurisdictional claims in published maps and institutional affiliations. 